\title{
Peculiarities of Teaching Business English to Ex-Servicemen and Their Family Members: Experience of Implementing Ukraine-Norway Project
}

\author{
Yu. V. Shevchenko*, H. A. Dyvnych \\ Chernihiv, Chernihiv National University of Technology, Chernihiv, Ukraine \\ *Corresponding author. E-mail: yulia_shevchenko_@ukr.net
}

Paper received 01.02.20; Accepted for publication 15.02.20.

https://doi.org/10.31174/SEND-PP2020-221VIII89-07

\begin{abstract}
The paper deals with the issue of teaching Business English to ex-combats and their family members. The authors outline the peculiarities of this group of learners. The challenges that teachers face in the targeted group are highlighted. The effective teaching strategies and classroom management techniques are suggested. The necessity of applying communicative, interactive methods and techniques of teaching and task based learning is proved. The importance to create favourable supportive learning environment where all learners can feel comfortable and perform to their maximum potential is emphasized.
\end{abstract}

Keywords: peculiarities, supportive learning environment, challenges, differentiation, classroom management, collaborative learning.

Introduction. Since 2003 the International Foundation for Social Adaptation together with Nord University and a network of Ukrainian universities and NGOs have been implementing the project "Ukraine-Norway: Retraining and Social Adaptation of Military Officers and Their Family Members in Ukraine", funded by the Royal Norwegian Ministry of Foreign Affairs [7]. The main tasks of the project are professional retraining of military personnel and their families in civil specialties that are in demand in the employment market, enhancing their professional competitiveness and psychological adaptation, increasing their motivation to active social adaptation in the civilian society with a market system of relations.

The main output of the project is the ability of the attendees to organize their own business or find proper employment after graduation. Modern business world demands at least basic knowledge of English for effective functioning and high results, therefore a course in Business English has been provided since 2019 for the attendees of the Ukraine-Norway project at Chernihiv National University of Technology studying "Internet technology, Web-design and English for Business".

Overview of publications. The issue of teaching English to adults has been studied by many scholars (Moss \& Ross-Feldman, Littlewood, B.Hird, M.Lewis, W.Lin, J.Lockwood, M.Oskarsson, A.OtwinowskaKasztelanic, O.Tarnopolsky, B.Tomlinson and others). Moss \& Ross-Feldman studied the influence of different factors such as age, anxiety and motivation on the foreign language learning (Moss \& Ross-Feldman, 2003). In the research of Littlewood, 2014; Richards \& Rodgers, 2001 the communicative-oriented approach in English teaching aimed at the development of communicative competence is promoted for specific learning situations. Task Based Learning are particularly valued for learner centeredness, authenticity of communicative situations, focus on students' needs (Willis, 2007, Herrin, 2009, Bilsborough, 2018). Presner R. devoted her dissertation to the scientific problem of learning foreign languages in the system of advanced education for adults (Presner R., 2017). Although considerable amount of research has been devoted to teaching English to adults, little attention has been paid to teaching Business English and no scholars devoted their research to teaching Business English in the framework of re-training ex-military.

The purpose of this paper is to define the methods and techniques that are the most appropriate and effective in teaching Business English to the attendees of the Ukraine-Norway project.

Materials and methods. Before considering the best practices and techniques of teaching Business English to the attendees of the Ukraine-Norway project, let's characterize the target audience. It's a group of special people - ex-military servicemen, ATO (antiterrorist operation) participants and their family members. The fact of participating in war and being under fire does not go unnoticed after returning to a peaceful life. Much of their behavioural stereotype relevant only for combat situations are so deeply rooted that they will be marked for many years. Therefore, all participants of military actions should go through a period of social and psychological rehabilitation [2, p. 60]. T.I. Kolenichenko adds that participation in hostilities is a very traumatic factor that leads to the destruction of the value system, the distortion of the outlook of the serviceman's personality [4, p. 29]. After returning to the conditions of civil life, excombatants have to re-engage in the process of peaceful life, learn to communicate with others, to renew or rebuild family and interpersonal relationships. T.I. Kolenichenko defines the re-socialization of excombatants as a multidimensional process of reassimilation by the combatant of social norms of behaviour, values, roles, instead of those that were characteristic for him before the participation in hostilities, which will result in normal and effective existence of the combatant in a peaceful society [5, p. 51]. It should be added, that specific behaviours are also characteristic to military servicemen without the experience of actual military actions, as their service conditions are strictly regulated and demand high level of personal subordination with all the sequences, which means that such social and psychological rehabilitation is needed for them as well. O.H. Lohvinova points out that the process of adaptation of servicemen to a peaceful life is complicated by the unreliability of social guarantees, their optional implementation by the state and the fall of economic stability of families of servicemen, the feeling of insecurity in the future [6, p. 75]. Regarding the family 
members of the participants of the military actions, we must note that some of them have lost their spouses or siblings in the war and have a painful burden of loss.

Considering mentioned above, we may conclude that the attendees of the Ukraine-Norway project have a number of specific skills and experience, their psychological state depends on the conditions of military service or participating in the war. There are some topics they may be very sensitive to. Some of the project attendees are inclined to strictly perform set tasks or, on the contrary, act as unquestionable leaders and may lack freedom of action or speech when performing creative tasks. This makes the process of teaching English extremely challenging and requires proper selection of teaching methods and techniques.

We are highly convinced that English lessons in the framework of the Ukraine-Norway project must be viewed not only as the lessons of foreign language acquisition but also as a means of group development and general communication skills improvement. So, in addition to developing foreign language communication skills, the process of teaching Business English in such a group should contribute to the project attendees grouping as a unity, developing the conditions for engaging all students, regardless of the level of language proficiency, creating an atmosphere of cooperation, interaction; comfortable learning conditions that would strengthen the feeling of learners' success, intellectual ability, security, uniqueness, significance.

To fulfil all these tasks, we consider to apply communicative, interactive methods and techniques, Task Based Learning (TBL) and functional approach to teaching English as far as they enable to accomplish all the goals mentioned above: to achieve not only good results in acquiring Business English language proficiency but also to promote the group development and socializing.

The peculiarities of teaching business English within the Project start with the organizational procedures. At the beginning, it's necessary to conduct "needs analysis" in order to find out what learners' needs are. It is useful to devise a needs analysis questionnaire, before designing syllabus. Armed with this information, a teacher can select the most appropriate and useful learning materials. According to modern approaches of teaching foreign languages the chosen topics should meet the areas of widest possible interests and needs of the majority of the students. Considering the content of the course we took into account the needs of learners and the fact that the majority of ex-military servicemen, ATO participants and their family members did not have any significant experience in business activity, so they didn't have profound background knowledge in business. Therefore, the main chosen topics were the following: socializing, applying for a job, writing $\mathrm{CV}$, job interview, meeting and negotiation, making business presentation, business travel, opening of a new business, developing business plans, advertising, negotiations. Moreover, some topics about culture differences were introduced in order to develop cultural awareness and skills necessary to function effectively in international business situations.

In addition, the entry test was held, that showed big extremes in English language proficiency: from
Elementary to Upper-Intermediate, which added specifics to group management. Consequently, the group was streamed into two subgroups according to the level of English. When there are only three months given for work, it is necessary to set up goals reachable within this period specifically for these students, and it is easier to do so when the level of English is approximately the same. The pace of studying in sub-groups was different, as well as the material processed. Thus, if a student felt that his/her sub-group was too slow for him/her or, on the contrary, he/she could not keep up with the groupmates, he/she was free to transfer to another sub-group. Such transferability also strengthened the individual and learner-centred approach to foreign language learning. Tasks involving groupwork could be adapted to the level and imply more or less teacher's assistance and quickly changed according to the learners' needs and challenges. However, it should be noted that, any group is considered to be more or less a mixed ability group where learners differ in the levels of English language proficiency and linguistic abilities. And if a group has great extremes in levels it makes a significant challenge to a teacher relating to teaching strategies, classroom management, appropriate differentiated materials, extra supplement texts and activities. No doubt, a teacher has to meet the needs of every learner of such a group encouraging cooperation and developing self-esteem. Thus, it is necessary to maintain proper classroom management and apply differentiated teaching instructions.

Let's outline essential elements that we, as educators, need to consider when deciding approaches to classroom management while teaching Business English to such a group. It's crucial to create a favourable supportive learning environment, organizing the classroom layout for maximum learning potential, involving all learners, cultivating a positive attitude, praise and encouragement. The attendees of the project turned out to be the adult learners who really needed psychological support in remembering their institute or even school knowledge of English and gaining confidence in the further process of learning Business English, and many of the participants with Elementary level tend to be very shy and scared of failure. What is more, using pair and group work meets their needs of peer-to-peer learning and feeling the support from each other. Monitoring the activity and asking for feedback help teachers to stay flexible and respond to the arising requests from the group of learners. It's necessary to maintain a learner-centred environment. The learners should be doing most of the talking and engaging, and the teacher should be a secondary figure who facilitates and monitors. Such approach also contributes to the group development, stimulates learners' confidence and independence, their ability to selfstudying and so, to their prospects of life-long learning.

It is important to note that much attention should be given to grouping, encouraging peer-to-peer support and cooperation, which is valuable for this specific target group. There are many techniques for grouping: learners can be organized according to their abilities, strong with weak ones or at random depending on teacher's objectives. Managing learners of different levels together for some activities is a good strategy, as it is proved that heterogeneous grouping provides access to more learning 
opportunities. It is commonly known that effective learning takes place when one student is asked to teach another one. It can be explained scientifically, as in order to teach someone, known information must be reorganized in brain. Thus, grouping more and less able learners can benefit both parties [8, p.27].

Ability grouping, on the other hand, is another way of grouping, that is especially useful under the conditions of limited time, giving all participants the opportunity to achieve reasonable goals. It lets the stronger and quicker students work with more complicated tasks, whereas the weaker students deal with a simpler task or work with a teacher as a group member supporting them and providing additional instruction and guidance. T. Ikina suggests the following ways to help weaker students: to give clear instructions using gestures, to make sure they understand the task, otherwise ask stronger students explain it in their mother tongue, to allow more thinking time and making notes before speaking activities, to reduce the word limit in productive activities, to give examples as model before writing activities, to pre-teach vocabulary using visual aids, to provide a rich variety of language and visual stimulants, to allow using dictionaries within reading comprehension tasks, to give a tape script while completing listening comprehension task, not to overcorrect their mistakes to avoid discourage [1, p.145].

Our teaching experience allows us to point out mingling as an effective method of group work. It is a productive classroom management strategy involving students in communicative interactions and increases their talking time. A mingle is an activity where a student approaches a groupmate, talks for a while and then moves on to speak to another groupmate. The distinctive features of a mingle activity are that all the students work simultaneously, in pairs or small groups, and switch from one groupmate to another while speaking, listening and taking notes. Mingles allow constant repetition of a particular question. This gives learners the opportunity to repeat the same utterance several times, which gradually raises confidence in their use of English. Mingles also enliven Business English lessons because students move around and talk to their group mates. Every new partner brings some novelty to the communicative situation and learners learn to take into consideration the characteristics of their interlocutors. To reach understanding, they need to speak clearly and sometimes explain certain points as they adjust to a new partner. As a result, the learners feel more relaxed and more involved. In addition, mingle activities at English lessons have the potential to improve interpersonal relations. Therefore, we highly recommend applying this classroom management strategy into teaching Business English to ex-military men and members of their families.

Proper classroom management is a prerequisite for implementing appropriate techniques and methods of Business English teaching, based on groupwork and interaction.

The main practical purpose of the Business English course within the Project was to develop students' confidence in expressing their views in English and improve their fluency, develop skills necessary for successful business performance in English language, thus raising their compatibility. Experts in teaching
English for specific purposes emphasize that focus should be more on functional and lexical aspects and rather than grammatical ones. Communicative language teaching focuses on developing learners' ability of communication in real life situations. Fluency in Business English is more important than accuracy. Therefore, more attention should be paid to essential business vocabulary and language chunks (useful phrases). In our course essential business vocabulary was presented and practiced through a wide variety of creative and engaging exercises and lexical games. Game factor can make words more memorable and help to involve every student into work with vocabulary. Gamification turned out to be one of the most efficient techniques for mastering new lexics and grammar, according to the learners' feedbacks.

What is more, the subgroup of Intermediate and UpperIntermediate level greatly benefited from task-based learning (TBL) and business cases method. It is considered to be very significant for teaching English for specific purposes, in particular Business English, since learners needs are to be able to perform tasks in relation to their jobs in a foreign language. This approach is based on the problem-solving view that a learners should be given some tasks to be solved. The learners interact and communicate with each other during solving these problems. In the completion of tasks, the teacher's role is as a facilitator who motivates and facilitates the students to speak during the completion of these tasks.

The researchers [3] summarize the following learning rational of a TBL approach:

- considering learners' needs and incorporating them in the task;

- drawing on learner's own input (experience, subject knowledge and intellectual ability);

- relating tasks to the real-world relationship;

- focusing on meaning;

- integrating the four language skills as well as soft skills;

- being goal oriented while undertaking tasks;

- evaluating outcomes when tasks are completed.

Business case study method fulfils defining characteristics regarding tasks [9, p.101]. Business case study brings the realities of the business world into classroom; it narrates the problems that face a company management telling the story up to the point where learners are left to analyse the dilemma and to solve the problems. During the case discussion, learners' attention is focused on meaning and they have a goal to be achieved. Business cases present realistic business situations and problems, which allow the learners to practice language they worked on during the lesson and let the teacher to organise a role play on their bases.

Having analysed the feedbacks of our learners, we noted that role-playing was one of the most enjoyable techniques. Role-plays appeal to the emotional sphere and enjoyment leads to effective learning. Learners use their background experiences, knowledge of business and make their own decisions thus, more interest and excitement are created in learning. Moreover, role-plays reduce the level of stress in shy students with low selfesteem, as less stress is involved in playing a role of someone else. 
Results and discussions. In order to evaluate the effectiveness of the above-mentioned approaches, methods and techniques to teaching Business English to ex-military and their family members, we conducted the entry, module and final assessment. The results showed improvements in the lexical competence by $40-50 \%$ in the middle of training and by $70-80 \%$ in the end of training; use of grammar improved by $20-40 \%$ and by $40-70 \%$ correspondingly; speaking skills assessment showed steady and great results throughout the course. Meeting with two visiting professors from Norway proved the general progress of the group and their ability to communicate in English. Moreover, it became visible that English classes contributed to positive group dynamics of the Project participants, motivating them to interact and share ideas, personal opinions, emotions and experience. Therefore, it becomes obvious that a teacher working with ex-military must be not only a good professional in teaching English, but also possess specific personal qualities and values to work effectively and create the necessary supporting learning environment.

We may state that implementation of the above mentioned techniques and approaches show high results within the three-months course of training. However, there is an issue that needs more consideration - the continuous long life learning of Business English after the end of the course: useful strategies, techniques and resources for self-studying.

Conclusion. To sum up, teaching Business English to ex-combats and their families is a great challenge involving implementation of a variety of teaching strategies, techniques and interaction patterns, taking into account the psychological characteristic of this group. Having studied the scientific works, monitored the effectiveness of our teaching experience, taking into consideration the feedbacks of the attendees, we can state that the most effective are interactive, communicative methods and techniques, task-based learning. Group work for fostering collaboration, real life interaction, developing self-esteem and unity with the whole group is of great importance to this category of learners. It is essential to create a favourable supportive learning environment, where all of them can feel comfortable and perform to their maximum potential. A teacher of Business English to such a group should be very sensitive not to be a trigger of negative emotions of ex-combats and their family members.

\section{REFERENCES}

1. Aikina T. Yu. Teaching English in Mixed Ability Classes//Young scientist, 2011. №11. T.2. P. 144-146. URL https://moluch.ru/archive/34/3908/.

1. Chapliak A.P., Romaniv O.P., Nad B.Ya. The main directions of rehabilitation of participants of hostilities//Ukraine. Nation's Health, 2018. № 3/1 (51). P. 59-61.

3. Ellis, R. Task-based research and language pedagogy//Language Teaching Research, 2000. 4(3), P. 193-220. http://dx.doi.org/10.1177/136216880000400302

4. Kolenichenko T.I. Reforming the system of organization of social and professional adaptation of servicemen, ATO/OOS veterans and their family members in Ukraine//Reforming the system of social services in Ukraine: problems and prospects: monograph/edited by Prof. N.I. Kryvokon. Chernihiv: CNUT, 2019. P. 21-45.

5. Kolenichenko T.I., Levytska N.S., Hrytsay S.O. Theoretical and methodological foundations of the problem of combatants re-socialization in Ukraine study//Issues of social work: philosophy, psychology, sociology. Chernihiv: CNUT, 2018. No. 2(12). P. 51-57.

6. Lohvinova O.H. Social-pedagogical adaptation of military personnel who returned from the ATO area by means of social-psychological training//SOCIOPROSTIR: the interdisciplinary online collection of scientific works on sociology and social work, 2018. № 7. P. 74-78.

7. Project "Ukraine - Norway". International Foundation for Social Adaptation. URL: https://ifsa.kiev.ua/en/projectukraine-norway/

8. Shevchenko Yu. V. Teaching English for Specific Purposes in Mixed Ability Groups//International Scientific and Practical Conference "WORLD SCIENCE" № 5(21), Vol.3, May 2017. Proceedings of the III International Scientific and Practical Conference "Scientific Issues of the Modernity" (April 27, 2017, Dubai, UAE). P. 25-28.

9. Wenhua Hsu. Harvard Business School (HBS) Case Method to Teaching English for Business Communication. Education and Linguistics Research 2016. Vol. 2 No. 2 URL: http://www.macrothink.org/journal/index.php/elr/article/view $/ 10192$ 